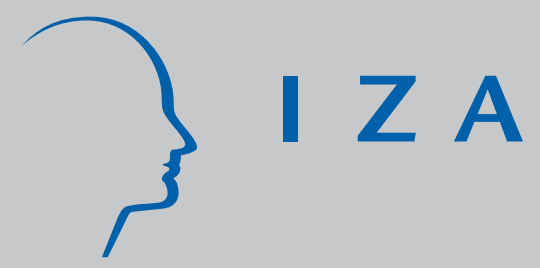

IZA DP No. 1142

Interethnic Marriages and Economic Assimilation of Immigrants

J asmin Kantarevic

May 2004 


\title{
Interethnic Marriages and Economic Assimilation of Immigrants
}

\author{
Jasmin Kantarevic \\ Ontario Medical Association, \\ University of Toronto and IZA Bonn \\ Discussion Paper No. 1142 \\ May 2004
}

\author{
IZA \\ P.O. Box 7240 \\ 53072 Bonn \\ Germany \\ Phone: +49-228-3894-0 \\ Fax: +49-228-3894-180 \\ Email: iza@iza.org
}

\begin{abstract}
Any opinions expressed here are those of the author(s) and not those of the institute. Research disseminated by IZA may include views on policy, but the institute itself takes no institutional policy positions.

The Institute for the Study of Labor (IZA) in Bonn is a local and virtual international research center and a place of communication between science, politics and business. IZA is an independent nonprofit company supported by Deutsche Post World Net. The center is associated with the University of Bonn and offers a stimulating research environment through its research networks, research support, and visitors and doctoral programs. IZA engages in (i) original and internationally competitive research in all fields of labor economics, (ii) development of policy concepts, and (iii) dissemination of research results and concepts to the interested public.
\end{abstract}

IZA Discussion Papers often represent preliminary work and are circulated to encourage discussion. Citation of such a paper should account for its provisional character. A revised version may be available on the IZA website (www.iza.org) or directly from the author. 


\section{ABSTRACT \\ Interethnic Marriages and Economic Assimilation of Immigrants*}

This paper examines the relationship between interethnic marriages and economic assimilation among immigrants in the United States. Two competing hypotheses are evaluated: the productivity hypothesis, according to which immigrants married to native-born spouses assimilate faster than comparable immigrants married to foreign-born spouses because spouses play an integral role in the human capital accumulation of their partners; and the selection hypothesis, according to which the relationship between intermarriages and assimilation is spurious because intermarried immigrants are a selected subsample from the population of all married immigrants. These two hypotheses are analyzed within a model in which earnings of immigrants and their interethnic marital status are jointly determined. The empirical evidence favors the selection hypothesis. Non-intermarried immigrants tend to be negatively selected, and the intermarriage premium obtained by the least squares completely vanishes once we account for the selection.

JEL Classification: J61, J12

Keywords: interethnic marriage, economic assimilation, self-selection

Jasmin Kantarevic

Institute for Policy Analysis

University of Toronto

140 St. George Street, Suite 616

Toronto, ON, M5S $3 G 6$

Canada

Email: jkantare@chass.utoronto.ca

\footnotetext{
* I thank Michael Baker, Aloysius Siow, and seminar participants at the University of Toronto and the Canadian Economics Association meeting in Ottawa, 2003 for many useful comments. All errors are mine. I also thank William Green for his assistance with Limdep. Financial support from the Canadian International Labour Network is gratefully acknowledged.
} 


\section{Introduction}

The marital behaviour of immigrants is a subject of great interest to sociologists. Interethnic marriage, defined as a marital union between a foreign-born and a native-born individuals, is considered to have important social implications for both immigrants and their host countries. Indeed, interethnic marriage lies at the heart of the study of intergroup relations. It is viewed to be both a measure of social assimilation and a factor producing it ${ }^{1}$.

Economic studies of interethnic marriages are scarce. Consequently, little is known about the economic implications of this type of marital behaviour. This paper attempts to examine one such implication: the relationship between interethnic marriages and the economic assimilation among immigrants. The logic behind this relationship is simple. The working hypothesis is that spouses directly affect the human capital accumulation of their partners $^{2}$. The magnitude of this effect depends on characteristics of spouses, such as their proficiency in the host country's language and their knowledge of local labour markets, which are likely to differ between native and immigrant spouses. As a result, the main testable implication of this hypothesis is that the earnings of intermarried immigrants must be significantly different from the earnings of otherwise identical immigrants who are married to immigrant spouses.

This subject integrates the literature concerned with the economic assimilation of immigrants and the marriage premium literature. First, studies of economic assimilation consistently find a positive correlation between earnings of immigrants and years elapsed since their arrival in the host country ${ }^{3}$. Yet, our understanding of the sources of this correlation is quite modest. While there are many variables that may influence the assimilation process, most empirical studies focused on one single factor - the proficiency in the host country's language ${ }^{4}$. Little is known about the importance of other factors, mainly because available data sets lack measures of human capital variables such as on the job training and job search activities. Interethnic marriage may be yet another important element in the assimilation process.

\footnotetext{
${ }^{1}$ See for example Lieberson and Waters (1986).

${ }^{2}$ An early example of this hypothesis is Benham (1974) who studied the effect of women's education on the earnings of their husbands. See also Welch (1974).

${ }^{3}$ For a comprehensive survey of this literature, see Borjas (1994) and (1999).

${ }^{4}$ See for example, McManus, Gould and Welch (1983), Grenier (1984), McManus (1985), McManus (1990), Chiswick (1991), and Chiswick and Miller (1992).
} 
In addition, and in contrast to many other potential determinants of assimilation, interethnic marriage is a variable that can be readily constructed from available data.

Second, while the interest in interethnic marriages is relatively new, the closely related literature on marriage premium is well beyond its infancy. An almost universal finding in this literature is that married men earn higher wages than do unmarried men, even after controlling for observable human capital variables. An important extension of these findings is to ask if and how does the marriage premium vary with the characteristics of potential spouses, and in particular whether labour market outcomes differ between immigrants married to native-born spouses and immigrants married to foreignborn spouses. In other words, is there an 'interethnic marriage premium'?

This paper is also motivated by a recent pioneering study by Meng and Gregory (2001) who document a positive correlation between interethnic marriage and the economic assimilation among immigrants in Australia. I extend their analysis by using data for the U.S. immigrants. Australia and the U.S. have very different ethnic composition of their immigrant population, and it is of interest to see whether Meng and Gregory (2001) findings extrapolate to the U.S. environment ${ }^{5}$.

A major impediment to the causal interpretation of the effect of interethnic marriage on the assimilation rate is that intermarried immigrants may be a selected subsample from the population of all married immigrants. For example, intermarried immigrants may possess characteristics that are valued in both labour and marriage markets, such as physical appearance. In addition, the decision to marry a native spouse or an immigrant spouse may be based on the expected gains from each type of marriage. In the marriage premium literature, the selection hypothesis is a real concern. Some researchers document that the effect of marriage on earnings may completely vanish once the selection is controlled for ${ }^{6}$. Based on these considerations, it is important to control for the possible selection effects when assessing the impact of interethnic marriages on the productivity of immigrants.

\footnotetext{
${ }^{5}$ For example, Chiswick and Miller (1995), who use both Australian and the U.S. Censuses in their study, report that among the foreign-born in Australia in 1981, 37\% were born in Britain and Ireland, $43 \%$ are from various other parts of Europe (mainly Southern Europe), 12\% from Asia and Africa, 4\% from New Zealand and 3\% from the Western hemisphere. In the U.S. an important fraction of the immigrants comes from the Central and South America.

${ }^{6}$ See Nakosteen and Zimmer (1987), and Cornwell and Rupert (1997).
} 
Disentangling the productivity effects of the interethnic marriage from the selection effects is quite challenging. To accommodate both hypotheses, I formulate and estimate a model in which earnings of immigrants and their interethnic marital status are jointly determined. A separate earnings function is specified for intermarried and nonintermarried immigrants, and the probability of interethnic marriage explicitly depends on the net difference in expected gains from each type of marriage. This model is a special case of endogenous switching regime models that have been extensively used in studies where the treatment variable may be endogenous ${ }^{7}$. In addition to the standard assumptions in this type of models, I rely on the variation in the relative marriage market conditions to assist in the identification of the treatment effect of interethnic marriage on the earning of immigrants, This variation is closely related to the sex ratio variable that has been used in many studies on the marital behavior of individuals ${ }^{8}$.

The main conclusion of this paper is that the selection hypothesis is important. According to the least square estimates, intermarried immigrants assimilate by about 2.5 percent faster than do non-intermarried immigrants. However, once we account for the selection, this interethnic marriage premium completely disappears. Nonintermarried immigrants tend to be negatively selected from the population of all married immigrants, while intermarried immigrants tend to be positively selected, although only for the former group the selection effect is statistically significant.

The paper is organized as follows. In the next section, I present the model of interethnic marriage and earnings to analyze the interaction between labour and marriage markets for immigrants. This section also discusses the empirical strategy and tests of assimilation effects. In section 3, I describe data and summary statistics, and in section 4 , I discuss the empirical results. Conclusions and suggestions for further research are presented in section 5.

\footnotetext{
${ }^{7}$ Maddala (1983) and (1984) contain a comprehensive survey and a list of applications. More recent survey on sample selection models is Vella (1998).

${ }^{8}$ Angrist (2000) contains a recent review of studies that examined the impact of sex ratio on various demographic and economic outcomes. See also Becker (1991) and GrossbardShechtman (1993).
} 


\section{Empirical Strategy}

\subsection{Background}

The existence of the male marriage premium has been documented across different data sets used ${ }^{9}$, across different countries ${ }^{10}$, and across different time periods studied ${ }^{11}$. The magnitude of the premium varies across studies and according to age, race and gender, but for white males it is quite large, with typical estimates in the range of 10-30\%. Overall, women do not earn a significant marriage premium, and black men typically earn smaller premiums than their white counterparts ${ }^{12}$.

The marriage premium literature has offered two main arguments to explain why married individuals receive higher wages than their unmarried counterparts ${ }^{13}$. First, marriage might raise the productivity of married men. Married men tend to accumulate more human capital than unmarried men because marriage makes greater specialization and division of labour within the household possible (Becker (1973)). Marriage may also alter the costs of investments in human capital (Kenny (1983)). Furthermore, men's productivity may be directly enhanced by their spouses (Benham (1974), GrossbardShechtman (1993), Daniel (1995)). A major alternative hypothesis is the selection hypothesis according to which marriage has no independent productivity effect on the earnings (Becker (1973), Grossbard-Shechtman (1993)). However, the researchers have failed to explain all the higher productivity

\footnotetext{
${ }^{9}$ For a partial summary of the data sets used in the studies of marriage premium, see Loh (1995).

${ }^{10}$ For example, Schoeni (1990) documents that male marital pay differentials are large and statistically significant in each of the twelve industrialized countries that he studies.

${ }^{11}$ Goldin (1990) documents the existence of the marriage premium for males as early as the end of the nineteenth century.

${ }^{12}$ Daniel (1995) develops and tests a model that explains why women typically do not earn marriage premium, and why the premium is smaller among blacks. Korenman and Neumark (1990) and (1988) also explore the relationship between marriage and pay for women and minority men, respectively.

${ }^{13}$ There are several other explanations found in the literature. A comprehensive survey is in Weiss (1997). For example, some argue that the marriage premium simply reflects employer favoritism. Reed and Harford (1988) suggest that married men receive a compensating differential because they work under adverse working conditions. Cornwell and Rupert (1997) argue that marriage induces a shift in the wage-generating process caused by the effect of "settling down".
} 
of men as the result of selection ${ }^{14}$. The empirical evidence suggests that the selection hypothesis may be important, but that even after controlling for the selection in various ways, there still remains a sizeable and significant productivity effect of marriage.

These arguments may be readily extended to explain why labour and marriage markets among immigrants may be significantly related. According to the productivity hypothesis, interethnic marriage may have a causal effect on the labour market productivity of immigrants. There are at least two reasons for this productivity effect. First, the degree of specialization and division of labour within the household may differ between interethnic and noninterethnic marriage. This difference may arise because native and immigrant spouses may have dissimilar preferences for work which determines the extent of potential specialization, and thus the gain from each type of marriage. Second, it is also possible that spouses play an integral role in the formation of human capital of their partners. For example, interethnic marriage can accelerate the linguistic adjustment of intermarried immigrants and enlarge their information and social network, and this may contribute positively to their labour market productivity.

Interethnic marriage need not always enhance the earnings of immigrants. Baker and Benjamin (1997) investigate the family investment hypothesis according to which immigrant couples may coordinate their investment activities in the presence of borrowing costs. For example, immigrant wives may take low paying jobs to finance their husbands' investments in human capital upon the arrival in the host country. Immigrants married to native-born spouses may not face binding borrowing constraints and they may accumulate less human capital than their nonintermarried counterparts. Consequently, the assimilation rate of intermarried immigrants may be smaller than that for nonintermarried immigrants. In this sense, the productivity effect we are seeking in this paper should be interpreted as the net effect of many, potentially conflicting, mechanisms by which the nativity of spouses may affect the earnings of immigrants.

On the other hand, the selection hypothesis postulates that the nativity of marriage partners and the work productivity of immigrants may be related even if the nativity of the partner does not affect productivity at all. This spurious relation may arise from omitting an important characteristic, such

\footnotetext{
${ }^{14}$ Excellent reviews of the empirical findings in the marriage premium literature are Korenman and Neumark (1991), Daniel (1995) and Loh (1995).
} 
as physical appearance ${ }^{15}$, that is valued in both labour and marriage markets. It is also likely that high earnings may increase the probability of becoming married to a native spouse, i.e. there may be assortative matching in the marriage markets. Immigrants may also select the type of marriage based on the expected gains from each type of marriage. In all these cases, intermarried immigrants may indeed be more productive, but interethnic marriage is not a causal factor for enhanced productivity.

This paper abstracts from other potential sources of selection. For example, immigrants may be a nonrandom sample of their home country population $^{16}$. In addition, persons who immigrate individually may be very different from individuals who immigrate with their families ${ }^{17}$. There are also important selection issues related to the marriage decision of immigrants ${ }^{18}$. These types of selection are important and they have been discussed in the literature. In this paper, I am concerned with the selection issues in the sample of married immigrants only. Consequently, the inference is limited to this restricted subsample of the immigrant population.

\subsection{The Model}

The alternative hypotheses about the effect of interethnic marriage can be analyzed within a model that is formally similar to that of evaluating the impact of any intervention or treatment ${ }^{19}$. Here, the treatment is the choice of interethnic marriage rather than noninterethnic marriage, and the impact I wish to evaluate is its effect on earnings of immigrants.

The structure of the model is as follows. A single immigrant chooses between a marriage to a native-born spouse $(j=1)$ and a marriage to a foreign-born spouse $(j=0)$ to maximize life-time utility. The utility from each type of marriage depends on its associated earnings and nonpecuniary benefits. Potential earnings in each marriage are determined by a standard set of human capital variables, but the returns to these variables are allowed to differ between the two types of marriages. Preferences for nonpecuniary

\footnotetext{
${ }^{15}$ For example, a study by Hamermesh and Biddle (1994) examines the relation between labour market performance and physical appearance of workers.

${ }^{16}$ See for example Borjas (1987).

${ }^{17}$ See Mincer (1978), and Borjas and Bronars (1991).

${ }^{18}$ See Angrist (2000).

${ }^{19}$ Main references are Maddala (1984), Heckman and Robb (1985), Heckman, LaLonde and Smith (1999), and Vella (1998).
} 
benefits vary between individuals, and these preferences are correlated with a set of background personal characteristics. Finally, the costs associated with each type of marriage are assumed to depend on individual characteristics and alternative-specific determinants of costs.

Even this simple structure accommodates both alternative hypotheses about the effect of interethnic marriages on earnings. To account for the productivity hypothesis, the potential earnings are allowed to differ between two types of marriages. The selection hypothesis is accommodated in the sense that the utility from each type of marriage explicitly depends on its associated earnings.

More formally, the utility $U_{i j \tau}$ of a single immigrant $i$ from marrying a spouse of nativity $j$, for $j=0,1$, is given by:

$$
U_{i \tau j}=\theta y_{i \tau j}+V_{i \tau} \vartheta_{j}+\eta_{i \tau j}
$$

where $y$ represents the (log of) potential earnings; $V$ is a vector of background characteristics related to preferences over nonpecuniary benefits; and $\eta$ represents other influences on the utility. $\theta$ and $\vartheta$ are parameters. $\tau$ indexes the cross-section in which the individual is observed, and I assume that there are at least two such cross-section surveys. This requirement will be explained later in the context of the separate identification of aging and cohort effects.

The cost for each type of marriage $C_{i j \tau}$ is represented as:

$$
C_{i \tau j}=B_{i \tau} \iota_{j}+\kappa N_{j}+\zeta_{i \tau j}
$$

where $B$ denotes a vector of individual characteristics; $N$ are alternativespecific determinants of costs; and $\zeta$ represent other influences on costs. $\iota$ and $\kappa$ are parameters.

A single immigrant's choice of the type of marriage is determined by the sign of the utility difference net of costs, $I_{i \tau}^{*}$, and is denoted by a categorical variable $I_{i \tau}$ :

$$
\begin{aligned}
I_{i \tau}^{*} & =\left(U_{i \tau 1}-U_{i \tau 0}\right)-\left(C_{i \tau 1}-C_{i \tau 0}\right) \\
I_{i \tau} & =1\left(I_{i \tau}^{*}>0\right)
\end{aligned}
$$

where $1($.$) is the indicator function.$ 
The potential earnings in each type of marriage are specified $\mathrm{as}^{20}$ :

$$
\begin{aligned}
y_{i \tau j} & =M_{i \tau} \omega_{j}+\alpha_{j} a g e_{i \tau}+\beta_{j} y s m_{i \tau}+\varkappa_{j} y_{o m_{i \tau}}+\sum \tau \mu_{\tau j} \pi_{i \tau}+\epsilon_{i \tau j} \\
& \equiv X_{i \tau} \rho_{j}+\varepsilon_{i \tau j}
\end{aligned}
$$

where $M$ gives a vector of human capital variables and other controls; age indicates the age of immigrant; ysm represents years since migration; yom is the year of immigration; and $\pi$ is a dummy variable indicating if immigrant $i$ was drawn from cross-section $\tau$. The second line is introduced to simplify exposition.

The separate identification of aging and cohort effects requires the availability of longitudinal data where a particular individual is tracked over time, or equivalently, the availability of a number of randomly drawn cross-sections so that specific cohorts can be tracked across survey years ${ }^{21}$. For this reason, I assume that at least two cross-section surveys are available for empirical application. An additional identification problem arises from the identity $y s m_{i \tau}=\sum \tau \pi_{i \tau}\left(T \tau-y_{o m_{i \tau}}\right)$, where $T \tau$ is the calendar year in which crosssection $\tau$ is obtained. To overcome this problem, I impose the usual identification restriction that the period effects are the same for both intermarried and nonintermarried immigrants:

$$
\mu_{\tau 1}=\mu_{\tau 0}
$$

Because earnings are observed in only one type of marriage for each individual, (3) is not useful for estimation as specified. However, substitution using (4) yields a reduced form equation for interethnic marriage:

$$
\begin{aligned}
& I_{i \tau}^{*}=W_{i t} \Gamma+u_{i t} \\
& I_{i \tau}=1\left(I_{i \tau}^{*}>0\right)
\end{aligned}
$$

where $W$ is the set of all exogenous variables in the earnings and interethnic marriage equations; and $u_{i t}$ is a composite error term. Equation (6)

\footnotetext{
${ }^{20}$ This specification is a standard one in the immigration literature. See for example Borjas (1999).

${ }^{21}$ See Borjas (1985) and Borjas (1999).
} 
determines sample selection into interethnic marriage, and can be estimated using standard discrete choice models such as Probit.

To complete the model, I assume that the residuals in the earnings equations and the interethnic marriage equation, $\left(\varepsilon_{1}, \varepsilon_{0}, u\right)$, are distributed jointly normal with mean zero and covariance matrix $\Sigma=\left[\sigma_{1}^{2}, \sigma_{10}, \sigma_{1 u}, \sigma_{0}^{2}, \sigma_{0 u}, \sigma_{u}^{2}\right]^{22}$. The model of interethnic marriage and earnings is thus fully specified by equations (4) and (6), with the assumed structure for disturbances, and subject to the restriction in equation (5).

The difference in the assimilation rate between intermarried and nonintermarried immigrants is defined as:

$$
\begin{aligned}
\phi^{*} & =\left.\frac{\partial y_{i}}{\partial t}\right|_{\text {intermarried }}-\left.\frac{\partial y_{i}}{\partial t}\right|_{\text {nonintermarried }} \\
& =\left(\alpha_{1}-\alpha_{0}\right)+\left(\beta_{1}-\beta_{0}\right)
\end{aligned}
$$

where $t$ denotes time, and the derivatives account for the fact that both age and years since migration change over time.

The main purpose of this paper is to test whether there is a causal effect of interethnic marriage on the assimilation rate of immigrants, or equivalently, whether $\phi^{*}$ is significantly different from zero. To test this hypothesis, we need consistent estimates of $\alpha_{1}, \alpha_{0}, \beta_{1}$, and $\beta_{0}$. The ordinary least square estimates of equation (5) will in general be inconsistent in the presence of selection of immigrants into interethnic marriages based on their unobserved characteristics. The self-selection in the present model is generated explicitly because the disturbance in the interethnic marriage equation (6) contains $\varepsilon_{1}$ and $\varepsilon_{0}$ that belong to the earnings equations. However, even weaker condition that the covariances $\sigma_{1 u}$ and $\sigma_{0 u}$ are nonzero will result in inconsistency of the OLS estimates.

Two consistent estimators in the presence of self-selection are the twostep Heckman correction method ${ }^{23}$ and the maximum likelihood estimator. Both of these estimators exploit the additional information in the interethnic marriage equation in estimating the parameters of the earnings equation. Note that:

$$
E\left[y_{i \tau} \mid I_{i \tau}=j\right]=X_{i \tau} \rho_{j}+E\left[\varepsilon_{i \tau} \mid I_{i \tau}=j\right]=X_{i \tau} \rho_{j}+\frac{\sigma_{j u}}{\sigma_{u}^{2}} \lambda_{i \tau j}
$$

\footnotetext{
${ }^{22}$ Note that $\sigma_{u}^{2}$ is not identified, and the usual convention is to normalize it to one.

${ }^{23}$ See Heckman (1979).
} 
for $j=0,1$; where $\lambda_{i \tau j}=f\left(W_{i t} \Gamma\right) / F\left(W_{i t} \Gamma\right)$ for intermarried immigrants $\left(I_{i \tau}=1\right)$, and $\lambda_{i \tau j}=-f\left(W_{i t} \Gamma\right) /\left[1-F\left(W_{i t} \Gamma\right)\right]$ for nonintermarried immigrants $\left(I_{i \tau}=0\right) . f$ and $F$ are the density function and the distribution function of a standard normal variable.

The $\lambda$ terms are known as the inverse Mills ratios, or simply the selectivity terms. Testing for the presence of selection is identical to testing that the coefficient on the selectivity terms is significantly different from zero. Equivalently, under the null hypothesis of no selection, $\sigma_{1 u}$ and $\sigma_{0 u}$ should be zero. In the case of positive selection of immigrants into interethnic marriages and the negative selection of immigrants into noninterethnic marriages, we have $\sigma_{1 u}<0$ and $\sigma_{0 u}>0$ (notice the minus sign in front of $\lambda$ for nonintermarried immigrants). In general, $\sigma_{1 u}$ and $\sigma_{0 u}$ may be of either sign.

In the two-step method, one first obtains the consistent estimates of the parameters $\Gamma$ in the interethnic marriage equation. These estimates are used to construct the selectivity terms $\lambda$. The OLS of earnings equations, with the selectivity terms included as additional regressors, then yields consistent estimates of $\rho_{1}$ and $\rho_{0}$. An additional adjustment needs to be made to correct the standard errors to account for the two-step nature of the estimation. Note that even after obtaining the selectivity terms, we need to estimate the earnings equations for intermarried and nonintermarried immigrants jointly in order to impose the cross-equation restriction (5). These equations were estimated by the generalized least squares method to account for the possible correlation between the error terms in two earnings equations.

The two-step estimates are never fully efficient in the sense that they never attain the Cramer-Rao lower bound. The efficient estimator is the full information maximum likelihood which estimates the earnings and interethnic marriage equations jointly. A potential problem, experienced in the empirical part of this study, is that the likelihood function is not concave and the iteration procedures need not always converge ${ }^{24}$. In few cases when the iteration has not completely converged, I report the two-step estimator which is a consistent estimator. All empirical results were estimated using LIMDEP $^{25}$.

\footnotetext{
${ }^{24}$ Maddala (1983) suggests using different initial values in the maximum likelihood estimation due to nonconcavity of the likelihood function. The default in LIMDEP is to set these initial estimates equal to the two-step estimates.

${ }^{25}$ I thank Bill Greene for useful correspondence.
} 


\subsection{Empirical Specification}

The measure of earnings used in this study is the logarithm of hourly wage ${ }^{26}$. I focus on this measure of earnings to isolate the impact of interethnic marriage on the productivity of immigrants. Measures such as annual wage income incorporate various dimensions of labour supply that may be endogenous. In addition, many studies in the marriage premium literature use this measure of earnings as the dependent variable ${ }^{27}$. The choice of covariates in the earnings equations (5) is similarly crucial, because some determinants of earnings may be influenced by interethnic marriage, such as fluency in the host country's language. The set of covariates in (5) is thus minimal and includes education ${ }^{28}$, and indicators for race (four) and regional residence (four) only. Since the educational attainment may be endogenous, I also estimated the model in the sample of immigrants who have completed their education prior to their marriage.

The interethnic marriage is defined as a marital union between any foreignborn and a native-born individual. Two remarks about this definition of interethnic marriage are worth noting. First, the 'nonintermarried' individual is any foreign-born person who is not married to a native. This definition does not require that nointermarrieds be necessarily married to individuals from the same country of origin ${ }^{29}$. Second, the above definition of intermarriage does not distinguish between first and subsequent generations of immigrants. For example, a foreign-born individual married to someone from his own ethnic group who was born in the U.S. would still be defined as intermarried ${ }^{30}$.

The identification of the earnings-interethnic marriage model does not require any exclusion restrictions. However, it is commonly agreed that the

\footnotetext{
${ }^{26}$ The hourly wage is constructed by the division of annual wage and salary income by the annual hours of work (a product of number of weeks worked in the previous year and the number of hours worked in the previous week).

${ }^{27}$ See for example Hill (1978), Korenman and Neumark (1991) and Loh (1995).

${ }^{28}$ The education variable is constructed from a set of educational attainment groups reported in the Census. Since the results are not affected by using a full set of educational dummy variables, the continuos variable representing the years of education is reported in all tables.

${ }^{29}$ However, in most cases the nonintermarrieds are married to individuals from their own country of origin. For example, among nonintermarried individuals in 1970, $77 \%$ were married to foreign-born individuals from the same country of origin. The corresponding figure for 1980 is $83 \%$.

${ }^{30}$ For a recent study that makes the distinction between different generations of immigrants, see Angrist (2000).
} 
exclusion restriction may assist in the identification due to the problems of multicollinearity between the selectivity terms and the exogenous variables in the earnings equations ${ }^{31}$. In this study, I exploit the variation in the relative marriage market conditions between different ethnic groups and states of residence. In particular, I consider the following instrument for the probability of interethnic marriage:

$$
Z_{i s g}=\left(\frac{m_{s g} / M_{g}}{n_{s} / N}\right)
$$

where $m_{s g}$ is the number of unmarried (never married, divorced, separated, and widowed) foreign-born individuals who reside in state $s$ and belong to ethnic group $g ; M_{g}$ is the total number of unmarried foreign-born individuals who belong to ethnic group $g$ in all states; $n_{s}$ is the number of unmarried native-born individuals who reside in state $s$; and $N$ is the total number of unmarried native-born individuals. All of these variables are defined for individuals of the opposite sex of immigrant $i$ and in the age group 16 to 65 years. In the construction of the instrument, I used appropriate Census weights.

This instrument is closely related to the sex ratio variable that has been extensively used in the studies of marital behaviour ${ }^{32}$. Theoretical link between the availability of potential spouses and the marriage decision of individuals was made explicit at least since Becker (1973). In this study, I expect the negative relationship between the instrument and the propensity of immigrants to intermarry, primarily because of the adverse effect of the relative availability of the potential spouses on the costs associated with each type of marriage.

The major objection to this instrument is that it is also a plausible instrument for marriage. If the propensity to marry across various ethnic groups and states of residence varies systematically with the variables that affect the earnings of immigrants, the instrument $Z$ would not be a valid exclusion restriction from the earnings equations. However, it is quite difficult to find an instrument that would be systematically related to the propensity to inter-

\footnotetext{
${ }^{31}$ See the discussion in Vella (1998) for example. Leung and Yu (1996) conclude from the Monte Carlo investigations that the Heckman two-step estimator is effective provided at least one of the independent variables displays sufficient variation to induce the tail behaviour in the inverse Mills ratio.

${ }^{32}$ See for example Angrist (2000), Becker (1991) and Grossbard-Shechtman (1993).
} 
marry but in the same time be unrelated to the probability of marriage. To partially address these concerns, all specifications reported include the lagged value of the instrument, $Z_{\tau-10}$ (the relative marriage market conditions ten years before the year in which I observe the immigrant). In addition, the inference is restricted to the sample of married immigrants only, and do not extrapolate to the larger population of all single immigrants.

In the empirical application, I experimented with several other definitions of this instrument. For example, I examined the sensitivity of results if unmarried individuals were defined as those who were never married. This definition may be more appropriate because the primary sample consists of individuals in their first marriage. I also considered the age group 16 to 32 years only, which may be more relevant because men on average tend to marry younger spouses.

\section{Data and Descriptive Statistics}

The data used in this study comes from the 1970 (Form 1 State) and 1980 (1\% Metro B Sample) U.S. Census samples of Integrated Public use Microdata Series (IPUMS-98) ${ }^{33}$. The particular choice of 1970 and 1980 samples was based on two criteria. First, the population of interest consists of all foreign-born individuals who arrived as unmarried to the U.S., since it is this group of immigrants who effectively face the choice of interethnic marriage. In 1970 and 1980 samples, it is possible to identify the age at first marriage. Combined with the information on year of immigration, the age at first marriage permits identification of whether individuals arrived as unmarried or not. Second, at least two samples from different time periods are required for the separate identification of cohort and aging effects, as discussed earlier. The 1970 and 1980 samples are two most recent samples that satisfy both of these criteria ${ }^{34}$.

From the larger sample of all foreign-born men, several selection rules were employed to produce the final samples used in the empirical analysis. First, the sample is restricted to all foreign-born males of age 16 to 65, married with spouse present, who do not reside in group quarters, and with nonmissing

\footnotetext{
${ }^{33}$ The IPUMS was created at the University of Minnesota in 1997, and it consists of twenty five samples which span the U.S. censuses of 1850 to 1990. The data sets and their full documentation is available at http://www.ipums.umn.edu/usa/doc.html.

${ }^{34}$ The information on age at first marriage is not available in the 1990 Census.
} 
information on own and spouse's place of birth, own year of immigration and own state of residence. Including females in the sample would raise additional selection problems related to their labour force participation. This problem is less severe in the case of males. In addition, the marriage premium literature finds weak evidence for the existence of marriage premium among females.

Second, only the individuals who are in their first marriage are included in the analysis. The sample is also restricted to individuals who arrived as unmarried. This selection rule results in a substantial loss of observations and I examine the sensitivity of the results to this rule by considering all married immigrants, regardless of whether they arrived as unmarried or not.

Third, I restrict the sample to individuals whose mother tongue is not English $^{35}$ and to individuals from ethnic groups that have at least fifty individuals in each Census year. The rationale for this selection rule is to ensure the reliability of the instrument, which varies by both ethnic groups and states of residence. In addition, we are more likely to find the evidence for the interethnic marriage premium in the sample of nonEnglish speaking immigrants if the effect of interethnic marriage works primarily through linguistic and information channels. I examine the sensitivity of results to this rule in detail in the empirical work.

Finally, all individuals with missing or zero annual wage, hours worked per week or weeks worked per year are excluded from analysis. In addition, the sample is trimmed by $1 \%$ from each tail of the distribution to reduce the impact of extreme observations on the estimation results ${ }^{36}$.

The resulting sample includes 9,129 immigrants (3,023 in 1970 and 6,106 in 1980). The average interethnic marriage rate is 37.95 per cent, with 3,464 immigrants married to a native-born spouse, and 5,665 immigrants married to a foreign-born spouse. Table 1 presents the interethnic marriage rate among ethnic groups. Several interesting patterns emerge. First, the variation in interethnic marriage rate is large among various ethnic groups. For example, in 1970 around 55\% of all individuals born in Germany were married to a spouse born in the U.S. The corresponding figure for individuals born in China was only 20\%. The average interethnic marriage rate was around $46 \%$ in the same year. Second, while interethnic marriage rate increased

\footnotetext{
${ }^{35}$ This rule excludes individuals whose place of birth is Australia, Canada, Ireland, New Zealand, and the United Kingdom.

${ }^{36}$ This rule effectively restrict the hourly wage to lie in $(\$ 1, \$ 67)$ interval, in the real 1990 dollars.
} 
or remained constant for few ethnic groups, most ethnic groups witnessed a substantial decline in the proportion of individuals married to native-born spouses. As a result, the overall interethnic marriage rate was about $12 \%$ lower in 1980 than it was in $1970^{37}$. Finally, the interethnic marriage rates among foreign-born individuals in the U.S. are slightly lower than the rates reported by Meng and Gregory (2001) for Australia. For example, among individuals who arrived in Australia at less than 20 years of age, the intermarriage rate was 48, 46, 48 and 47 percent in 1981, 1986, 1991 and 1996, respectively.

Table 2 compares the hourly wage and annual wage and salary income between intermarried and nonintermarried immigrants. This table also includes an estimate of unadjusted interethnic marriage premium obtained from a regression of log hourly wages (log annual wage income) on an indicator of interethnic marital status, with no other covariates in the regression. Consider the hourly wages first. The earnings of intermarried immigrants were higher in both 1970 and 1980 than earnings of nonintermarried immigrants. The difference amounts to about $\$ 0.74$ in 1970 to $\$ 0.56$ in 1980 , which translates into 4 to 5 percent of real earnings. This premium is significant in both years. The real hourly earnings are lower in 1980 than they were in 1970 for both groups of immigrants. Similar differences can be observed in the annual wage income between intermarried and nonintermarried immigrants. The premium in the annual income was about 8\% in both 1970 and 1980, or an equivalent of $\$ 1,797$ and $\$ 1,926$ per year. Again, this difference is statistically significant in both years. The variation in both hourly wages and annual wage income is substantial for both groups of immigrants, but does not seem to be considerably different between the two groups. Finally, compared to the interethnic marriage premium in annual income that Meng and Gregory (2001) report for Australia, the premium in the U.S. is substantially smaller. Over the 1981 to 1996 period, the interethnic premium in Australia was between 9 and 20 percent for immigrant males who arrived in Australia at less than twenty years of age.

Table 3 reports the summary statistics by interethnic marital status. The

${ }^{37}$ A separate investigation of the flow into interethnic marriages using the Vital Statistics Marriage files revealed that the proportion of foreign-born individuals who were intermarrying every year over the 1970 to 1980 period was relatively constant at about fifty two percent. The reason for the lower intermarriage rate in 1980 probably has to do more with the determinants of the outflows from the interethnic marriage such as divorce and mortality rates. 
first two moments of the age distribution are almost identical between intermarried and nonintermarried immigrants. On the other hand, intermarried immigrants spent more years in the U.S. and acquired more education than did nonintermarried immigrants. The distribution of intermarried and nonintermarried immigrants across different Census regions is very similar. Most of intermarried and nonintermarried immigrants in both years are white. However, the proportion of nonintermarried immigrants who are Asian was $12 \%$ in 1970 and $17 \%$ in 1980, which is larger than their proportion in the total sample ( 7 and 14 percent, respectively). The distribution of intermarried immigrants is clearly skewed toward the earlier iimigrant cohorts, while the distribution of nonintermarried immigrants is more symmetric.

In sum, this preliminary inspection of the data shows that there is a substantial variation in the interethnic marriage rate among different ethnic groups. In addition, intermarried immigrants enjoy a sizeable wage premium, both in hourly wages and in annual wage income. Finally, intermarried and nonintermarried immigrants differ in certain determinants of earnings such as age and year of immigration, and it may be important to control for these differences in the multivariate regression framework.

\section{Results}

\subsection{Probability of Interethnic Marriage}

Table 4 presents the maximum likelihood Probit estimates of the interethnic marriage equation (6). For purposes of comparison, the estimates from linear probability model are also shown, and the Probit estimates are presented as marginal effects, evaluated at the mean of independent variables. Since the interethnic marriage equation (6) is in the reduced form, the estimates must be interpreted as capturing both the direct effects on interethnic marital status and indirect effects through earnings.

The estimated effect of the instrument $Z_{i g \tau}$ - the relative availability of the potential spouses from the same ethnic group and in the same state of residence as immigrant $i$ - is negative as expected, and one of the most significant determinants of interethnic marriage. Controlling for the current value of $Z$, the impact of $Z_{i g \tau-10}$ is positive and significant. Given the current relative marriage market conditions, the past values of $Z$ indicate how well the ethnic group is established in the country. The interethnic marriage 
rates are expected to be higher among the well-established groups, because these groups tend to be relatively more assimilated. In addition, there is a larger number of the second-generation individuals in these ethnic groups who would count as native-born in this study. The chi-square test of the joint significance of $Z_{i g \tau}$ and $Z_{i g \tau-10}$ clearly rejects the null hypothesis of no significance $^{38}$.

Most of other variables have expected signs. The probability of interethnic marriage is a decreasing and concave function of age. Better educated immigrants are more likely to become intermarried. The interethnic marriage seems to be significantly higher in the West as compared to other regions. Black immigrants and immigrants of other races tend to intermarry more than do white immigrants, while Asian immigrants are significantly less likely to intermarry. Immigrants who spent more years in the U.S., as well as earlier immigrant cohorts in general, have higher propensity to intermarry. This may reflect the changing composition of immigrant cohorts over time, the changes in the relative marriage market conditions, or the changing tastes for heterogamous marriages as a part of the cultural assimilation process. Finally, the interethnic marriage was about six percent lower in 1980 than it was in 1970.

The estimates obtained from the linear probability model are very similar to the Probit estimates. Logit estimates, not presented here, are also almost identical to the ordinary least squares and Probit estimates.

\subsection{Main Results}

Tables 5 and 6 present the main results of this paper. In table 5, I present the estimates of the parameters of the earnings equations obtained from three alternative estimators: the generalized least squares (seemingly unrelated regression), the maximum likelihood estimates, and the two step Heckman estimates. Table 6 shows the difference in the estimated coefficients of the earnings equation between intermarried and nonintermarried immigrants.

Consider the results for intermarried immigrants in table 5a first. The first column presents the GLS estimates. The hourly earnings are increasing and concave function of age. In particular, each additional year of age brings about eight percent increase in real hourly earnings. Education also positively

\footnotetext{
${ }^{38}$ The chi-square statistic is 145.51 and the associated p-value is zero to four decimal places. In a regression not reported here, the coefficient of $Z_{i g \tau-10}$ was negative and significant when $Z_{i g \tau}$ was excluded from the regression.
} 
affects earnings, and each additional year of schooling results in about a four percent increase in the hourly wage. The earnings of intermarried immigrants are on average lower in the South and West regions. In comparison to white intermarried immigrants, members of other racial groups earn less, although this difference is significant for the black race only. There are no significant individual cohort effects on real hourly earnings, and these effects are not significant even jointly ${ }^{39}$. Real hourly earnings are about five percent lower in 1980 than they were in 1970. Finally, the earning increase with each year spent in the host country but at diminishing rate.

The maximum likelihood estimates are very similar to the GLS estimates. This is not surprising because the estimated covariance between the error term in the earnings equation and the interethnic marriage equation is very small in magnitude (-0.03) and highly insignificant (t-ratio us -0.24). This result suggests that selection hypothesis may not be important in the sample of intermarried immigrants, although the sign of $\sigma_{1 u}$ is indicative of positive selection. The two-step Heckman estimates confirm this finding. The estimated coefficient on the selectivity term is negative, but again highly insignificant. As a result the estimated coefficients of most other independent variables are not very different from the GLS estimates.

Table $5 \mathrm{~b}$ contains the results for the nonintermarried immigrants. As in the sample of intermarried immigrants, the GLS estimates show that hourly earnings are increasing and concave function of age. More educated immigrants earn more; earnings in the South and West regions are lower; and white nonintermarried immigrants enjoy a wage premium. The individual cohort effects are in general much smaller for nonintermarried immigrants than for intermarried immigrants, and they fail to attain significance both individually and jointly.

The maximum likelihood estimates and the two-step estimates present evidence of negative selection. In particular, the estimated $\sigma_{0 u}$ is 0.21 with t-ratio of 2.00, while the estimated coefficient of the selectivity term $\lambda_{0}$ is -1.74 with t-ratio of -1.91 . In addition, the estimated returns to age are higher than the estimates obtained by the GLS. The cohort effects suggest that the more recent cohorts may earn more than earlier cohorts, but these effects are not significant either individually or jointly ${ }^{40}$.

\footnotetext{
${ }^{39}$ The chi-square statistic for intermarried immigrants is 4.52 with associated p-value of 0.2107. The corresponding figures for nonintermarried immigrants are 4.52 and 0.2108.

${ }^{40}$ The p-value for the Wald test of the joint significance of cohort effects is 0.1552 the intermarried immigrants, and 0.3999 for nonintermarried immigrants.
} 
The difference in the estimated coefficients of the earnings equation between intermarried and nonintermarried immigrants is presented in table 6 . Based on the GLS estimates, the only significant difference between intermarried and nonintermarried immigrants is in the returns to age. In particular, intermarried immigrants receive about four percent more than similar nonintermarried immigrants for each year of age. Interestingly, intermarried immigrants' earnings grow by about 1.5 percent less than earnings of nonintermarried immigrants with each year spent in the host country. However, this difference is not significant at the conventional level of significance. The estimate of the assimilation effect is 2.5 percent and the associated p-value is 0.054 .

The maximum likelihood estimates also show that the only significant difference between intermarried and nonintermarried immigrants is in the estimated returns to age. However, the estimated difference is only about 3.2 percent, mainly because the maximum likelihood estimates of the returns for age for nonintermarried immigrants tend to be higher than the corresponding GLS estimates. The difference in the returns to each year spent in the host country is negative, statistically insignificant and very similar to the GLS estimate. The estimated assimilation effect based on the maximum likelihood estimates is only 1.5, almost one percent lower than the GLS estimate. However, this effect is insignificant at the conventional level (the associated $\mathrm{p}$-value is -.18).

The two-step estimates also suggest smaller differences in the returns to age, and insignificant difference in the returns to years since migration. The estimated assimilation effect is about two percent but this effect is not statistically significant from zero.

I conclude this section with two remarks. First, the large GLS estimate of the assimilation effect of 2.5 percent appears to be completely explained by the selection of immigrants into the two types of marriages. The assimilation effect using either the maximum likelihood or the two-step Heckman procedure is not statistically different from zero, even though the point estimates are close to those obtained by the GLS.

Second, the assimilation effect is attributable to the difference in 
the returns to age between intermarried and nonintermarried immigrants. I offer two possible explanations for this result. One explanation is simply that the intermarried immigrants immigrated at younger age than did nonintermarried immigrants. Consequently, the general experience of intermarried immigrants is based more on their experience in the host country than in the home country, which is more relevant to their current productivity. Another possible explanation is that the experience of intermarried immigrants in their home countries was more valuable that the experience of nonintermarried immigrants. For example, immigrants working in the foreign branches of the U.S. firms receive general experience that is valued in the U.S. In addition, these immigrants may be more likely to intermarry if they migrate to the U.S. because of their relative familiarity with the social customs and norms in the U.S. prior to their migration.

\subsection{Specification Checks}

Table 7 contains additional specification checks of the model. First, I experimented with several other definitions of the instrument. In particular, I examined the sensitivity of results if unmarried individuals were defined as those who were never married and if the age group was restricted to 16 to 32 years potential spouses only. The estimated assimilation effect from the two-step method ranges between 1.80 and 2.00 percent, which is very similar to the estimates obtained using the initial specification. In addition, the estimated coefficients on the selectivity terms almost always indicate positive selection into interethnic marriages and negative selection into marriages with other foreign-born individuals. However, only the latter coefficients are statistically significant in all specifications. These results suggest that the results are not particularly sensitive to minor variations in the definition of the instrument.

Second, I estimated the model in the sample of individuals who have completed their education prior to their first marriage. In this calculation, I have assumed that individuals have been in school until they completed their education and have not returned to the school afterwards ${ }^{42}$. In this sample, the GLS estimate of the assimilation effect is slightly larger, 2.8 percent and significant at 5 percent level. The two step estimate of the assimilation effect

\footnotetext{
${ }^{42}$ In particular, all individuals for whom (age-6-education) was greater than the age at first marriage are excluded from the analysis.
} 
is 1.27 percent, but it is imprecisely estimated. The signs of the coefficients of selectivity terms confirm the presence of positive selection in the sample of intermarried immigrants, and the negative selection in the sample of nonintermarried immigrants. Again, only the coefficient on the selectivity term for nonintermarried immigrants attains statistical significance.

Finally, consider the sample of English-speaking immigrants only. These include individuals born in Australia, Canada, Ireland, New Zealand, and the United Kingdom. If the assimilation effect of interethnic marriage works primarily through the linguistic adjustment, we should also observe no effect of interethnic marriage on this group of foreign-born individuals. This intuition is confirmed by the results. The point estimate of the assimilation effect is much smaller than in the group of nonEnglish-speaking immigrants, and neither the GLS nor the two-step estimates indicate significant difference in the assimilation rate between intermarried and nonintermarried immigrants. Importantly, the results also indicate that the selection is not important in this group of immigrants.

\section{Conclusions}

While substantial empirical evidence suggest the presence of economic assimilation among immigrants in many countries, little is know about the underlying factors explaining this phenomenon. In this paper, I have explored the possibility that immigrants who marry spouses born in the host country accumulate human capital relatively faster than immigrants married to foreign-born spouses. The ordinary least square estimates confirm this prediction and indicate that intermarried immigrants enjoy growth rate in their earnings that exceeds that for nonintermarried immigrants by close to 2.5 percent. However, this relationship appears to be spurious. Once an appropriate control is taken of the fact that immigrants may select into different types of marriages, the assimilation effect of intermarriage disappears. The evidence indicates that intermarried immigrants tend to be positively selected among all married immigrants, while nonintermarried immigrants tend to be negatively selected.

These results are in contrast with findings of Meng and Gregory (2001) who find evidence of substantial interethnic marriage premium for nonEnglish speaking immigrants in Australia. While there are many potential reasons why the results between these two studies differ, an important factor appears 
to be the composition of immigrant population in the U.S. compared to Australia. The future research should shed more light on this issue.

Another potential avenue for future research is to examine other labor market outcomes such as geographic and occupational mobility for example. It would also be of interest to examine the assimilation effect of interethnic marriages in the sample of female immigrants, with the associated selection problem of controlling for their labour market participation. The additional sources of selection - such as selection related to immigration and marriage decisions - may also be incorporated in future work. Another important extension of this study is to examine intermarriages and assimilation of immigrants in other countries. We are but at the beginning of understanding the complex link between labour and marriage outcomes for immigrants, and a lot of work remains to be done. 


\section{References}

1. Angrist, J. (2000) "Consequences of imbalanced sex ratios: evidence from America's second generation", NBER Working Paper 8043.

2. Baker, M. and Benjamin, D. (1997) "The role of the family in immigrants' labor-market activity: an evaluation of alternative explanations", The American Economic Review 87(4): 705-727.

3. Becker, G.S. (1973) "A theory of marriage: Part I", Journal of Political Economy 81(4), 813-846.

4. Becker, G.S. (1974) "A theory of marriage: Part II", Journal of Political Economy 82(2), S11-S26.

5. Becker, G.S. (1991) A treatise on the family. (Harvard University Press)

6. Benham, L. (1974) "Benefit's of women's education within marriage", The Journal of Political Economy 82(2): S57-S71.

7. Borjas, G. (1985) "Assimilation, changes in cohort quality, and the earnings of immigrants". Journal of Labor Economics 3(4): 463-489.

8. Borjas, G. (1994) "The economics of immigration", Journal of Economic Literature 32(4): 1667-1717.

9. Borjas, G. (1999) "The economic analysis of immigration", in: O. Ashenfelter and D. Card,eds., Handbook of labor economics, Volume 3A. (Amsterdam, North Holland).

10. Daniel, K. (1995) "The marriage premium", in: M.Tomassi and K.Ierulli, eds. The new economics of human behavior (Cambridge University Press, London).

11. Grossbard-Shechtman (1993). On the economics of marriage: a theory of marriage, labor and divorce. (Westview Press, Boulder, CO).

12. Heckman, J. (1979) "Sample selection as a specification error", Econometrica 47: 153-161. 
13. Heckman, J. and Robb, R. (1985a) "Alternative methods for evaluating the impact of interventions", in: J. Heckman and B. Singer, eds., Longitudinal analysis of labor market data (Cambridge University Press for Econometric Society Monograph Series, New York).

14. Heckman, J., Lalonde, R., and Smith, J. (1999) "The economics and econometrics of active labor market programs", in: O. Ashenfelter and D. Card,eds., Handbook of labor economics, Volume 3A. (Amsterdam, North Holland.)

15. Hill, M.S. (1978) "The wage effects of marital status and children". The Journal of Human Resources 14(4): 579-594.

16. Kenny, L. (1983) "The accumulation of human capital during marriage by males". Economic Inquiry 21(2): 223-231.

17. Korenman, S. and Neumark, D. (1991) "Does marriage really make men more productive". The Journal of Human Resources 26(2): 282-307.

18. Lieberson S., Waters MC. (1986) "Ethnic groups in flux: the changing ethnic responses of American whites", Annual American Academy of Political and Social Sciences, 487: 79-91.

19. Loh, E.S. (1995) "Productivity differences and the marriage premium for white males". The Journal of Human Resources 31(3): 566-589.

20. Maddala, G.S. (1983) Limited dependent and qualitative variables in econometrics (New York, Cambridge University Press).

21. Maddala, G.S. (1984) "Disequilibrium, self-Selection, and switching models", in: Z. Griliches and M. Intriligator, eds., Handbook of econometrics, Volume 3. (Amsterdam, North Holland).

22. Meng, X. and Gregory, R.G. (2001) "Intermarriage and the economic assimilation of immigrants", Australian National University, unpublished manuscript.

23. Nakosteen, R. and Zimmer, M. "Marital status and earnings of young men". Journal of Human Resources 22(2): 248-268.

24. Welch, F. (1974) "Benefit's of women's education within marriage: comment", The Journal of Political Economy 82(2): S72-S75. 
25. Weiss, Y. (1997) "The formation and dissolution of families: why marry? Who marries whom? And what happens upon divorce"", in: M.R. Rosenzweig and O.Stark, eds., Handbook of population and family economics, Volume 1A. (Amsterdam, Elsevier Science). 
Table 1. Interethnic marriage rate, 1970 and 1980 U.S. Census

Percentage of the group intermarried in:

\begin{tabular}{lcccc} 
Ethnic group & $\begin{array}{c}1970 \\
\text { Census }\end{array}$ & $\begin{array}{c}1980 \\
\text { Census }\end{array}$ & $\begin{array}{c}\text { Both } \\
\text { Censuses }\end{array}$ & $\begin{array}{c}\text { Group size } \\
\text { (both Censuses) }\end{array}$ \\
\hline Germany & 0.5484 & 0.6417 & 0.6015 & 1,079 \\
Hungary & 0.5517 & 0.4868 & 0.5215 & 163 \\
Italy & 0.5817 & 0.4553 & 0.5166 & 1,173 \\
Poland & 0.4221 & 0.4167 & 0.4197 & 355 \\
Greece & 0.4239 & 0.3910 & 0.4032 & 248 \\
Mexico & 0.4856 & 0.3298 & 0.3654 & 2,592 \\
West Indies & 0.4198 & 0.2897 & 0.3245 & 490 \\
Russia & 0.4253 & 0.1846 & 0.3224 & 152 \\
South America & 0.2875 & 0.3252 & 0.3146 & 569 \\
Portugal & 0.4706 & 0.2517 & 0.3093 & 194 \\
Central America & 0.2982 & 0.2839 & 0.2867 & 293 \\
Yugoslavia & 0.3789 & 0.1942 & 0.2828 & 198 \\
Cuba & 0.3376 & 0.2366 & 0.2646 & 567 \\
Philippines & 0.3485 & 0.1467 & 0.2000 & 500 \\
China & 0.2000 & 0.1502 & 0.1637 & 556 \\
All ethnic groups & 0.4591 & 0.3400 & 0.3795 & \\
(standard error) & $(0.4984)$ & $(0.4737)$ & $(0.4853)$ & \\
Observations & 3,023 & 6,106 & 9,129 & \\
\hline
\end{tabular}

Notes:

(1) Interethnic marriage rate is defined as the fraction of all married foreign-born persons who are married to native-born spouses.

(2) All estimates are weighted by the Census weights.

(3) Ethnic groups are ranked in the decreasing order of their interethnic marriage rate in both 1970 and 1980 Censuses.

(4) Group size is the number of unweighted observations for each ethnic group in both 1970 and 1980 Censuses. 
Table 2. Unadjusted interethnic marriage premium

\begin{tabular}{|c|c|c|c|c|}
\hline & \multicolumn{4}{|c|}{1970} \\
\hline & \multicolumn{2}{|c|}{ Hourly Wage } & \multicolumn{2}{|c|}{ Annual Wage Income } \\
\hline & Mean & St. Deviation & Mean & St. Deviation \\
\hline Intermarried & 15.02 & 8.67 & 30,315 & 17,415 \\
\hline Nonintermarried & 14.28 & 8.19 & 28,158 & 16,636 \\
\hline Premium (\$) & $\$ 0.74$ & & $\$ 1,797$ & \\
\hline \multirow[t]{4}{*}{ Premium $(\%)$} & $4.48 \%$ & [2.16] & $7.69 \%$ & [3.36] \\
\hline & \multicolumn{4}{|c|}{1980} \\
\hline & \multicolumn{2}{|c|}{ Hourly Wage } & \multicolumn{2}{|c|}{ Annual Wage Income } \\
\hline & Mean & St. Deviation & Mean & St. Deviation \\
\hline Intermarried & 13.85 & 8.11 & 28,274 & 17,834 \\
\hline Nonintermarried & 13.29 & 8.39 & 26,348 & 17,065 \\
\hline Premium (\$) & $\$ 0.56$ & & $\$ 1,926$ & \\
\hline Premium (\%) & $4.78 \%$ & [2.98] & $7.64 \%$ & {$[4.18]$} \\
\hline
\end{tabular}

Notes:

(1) The nominal wages are adjusted for inflation using the Consumer Price Index (CPI) included in the Census. The CPI was 3.39 in 1970 and 1.71 in 1980, relative to 1990.

(2) All estimates are weighted by the Census weights.

(3) The interethnic marriage premium (\%) is obtained from a regression of log hourly wage (log annual wage income) on an indicator of interethnic marital status, with no other covariates included in the regression.

(4) The sample size is 3,023 in 1970, and 6,106 in 1980. 
Table 3. Summary statistics, by interethnic marital status. 1970 1980 NonNonIntermarried intermarried Intermarried intermarried

\begin{tabular}{lcccc}
\hline Age & 37.65 & 37.50 & 34.02 & 35.24 \\
& $(11.03)$ & $(10.24)$ & $(9.10)$ & $(9.15)$ \\
Years since migration & 18.85 & 14.74 & 18.39 & 14.71 \\
& $(6.97)$ & $(7.57)$ & $(7.38)$ & $(7.21)$ \\
Education & 11.44 & 10.60 & 12.24 & 11.26 \\
& $(3.93)$ & $(4.03)$ & $(4.02)$ & $(4.27)$ \\
Northeast Region & 0.47 & 0.46 & 0.32 & 0.31 \\
Midwest Region & 0.17 & 0.15 & 0.16 & 0.11 \\
South Region & 0.10 & 0.09 & 0.21 & 0.16 \\
West Region & 0.25 & 0.30 & 0.31 & 0.41 \\
White race & 0.92 & 0.84 & 0.87 & 0.76 \\
Black race & 0.03 & 0.04 & 0.05 & 0.06 \\
Asian race & 0.04 & 0.12 & 0.05 & 0.17 \\
Other race & 0.01 & 0.01 & 0.03 & 0.02 \\
Immigrated before 1949 & 0.49 & 0.27 & 0.11 & 0.04 \\
Immigrated 1950-1959 & 0.37 & 0.38 & 0.37 & 0.21 \\
Immigrated 1960-1969 & 0.14 & 0.35 & 0.32 & 0.42 \\
Immigrated 1970-1979 & 0.00 & 0.00 & 0.20 & 0.33 \\
& & & & \\
Number of observations & 1,388 & 1,635 & 2,076 & 4,030 \\
\hline
\end{tabular}

Notes:

(1) All estimates are weighted by the Census weights. Standard errors are in parentheses.

(2) Asian race includes Chinese, Japanese and other Asian or Pacific. 
Table 4. Probability of interethnic marriage.

\begin{tabular}{|c|c|c|c|c|}
\hline & \multicolumn{2}{|c|}{ Probit } & \multicolumn{2}{|c|}{ LPM } \\
\hline & Coefficient & z-ratio & Coefficient & t-ratio \\
\hline $\mathrm{Z}$ & -0.4670 & -6.61 & -0.4362 & -7.02 \\
\hline $\mathrm{Z}$ lagged & 0.1456 & 1.97 & 0.1537 & 2.37 \\
\hline Age & -0.0411 & -10.47 & -0.0351 & -10.21 \\
\hline $100 * \mathrm{Age}^{2}$ & 0.0349 & 7.06 & 0.0291 & 6.67 \\
\hline Education & 0.0098 & 6.99 & 0.0094 & 7.71 \\
\hline Midwest & -0.0025 & -0.14 & 0.0008 & 0.05 \\
\hline South & 0.0246 & 1.47 & 0.0222 & 1.52 \\
\hline West & 0.0538 & 3.33 & 0.0507 & 3.63 \\
\hline Black race & 0.0681 & 2.51 & 0.0554 & 2.38 \\
\hline Asian race & -0.2325 & -13.28 & -0.2181 & -13.61 \\
\hline Other race & 0.0988 & 2.48 & 0.0848 & 2.47 \\
\hline Immigrated before 1949 & 0.2595 & 4.42 & 0.2362 & 4.75 \\
\hline Immigrated 1950-1959 & 0.0976 & 2.32 & 0.0859 & 2.37 \\
\hline Immigrated 1960-1969 & -0.0092 & -0.38 & -0.0098 & -0.47 \\
\hline Year 1980 indicator & -0.0612 & -2.87 & -0.0530 & -2.85 \\
\hline Years since immigration & 0.0154 & 3.38 & 0.0136 & 3.50 \\
\hline $100 *$ Years since immigration ${ }^{2}$ & 0.0032 & 0.22 & 0.0035 & 0.28 \\
\hline constant & & & 0.9471 & 14.52 \\
\hline \multicolumn{5}{|l|}{ Adjusted R ${ }^{2}$} \\
\hline Observed P & \multicolumn{2}{|c|}{0.3795} & & \\
\hline Predicted P (at mean X) & \multicolumn{2}{|c|}{0.3618} & & \\
\hline Log likelihood & \multicolumn{2}{|c|}{$-5,214$} & & \\
\hline Number of observations & \multicolumn{4}{|c|}{9,129} \\
\hline
\end{tabular}

Notes:

(1) LPM stands for linear probability model.

(2) Probit estimates are evaluated as the marginal change in the probability, evaluated at the mean of independent variables.

(3) Instruments $\mathrm{Z}$ and $\mathrm{Z}$ lagged are as defined in the text. 
Table 5a. Estimates of the earnings equations, intermarried immigrants.

\begin{tabular}{|c|c|c|c|c|c|c|}
\hline & \multicolumn{2}{|c|}{ GLS } & \multicolumn{2}{|c|}{ 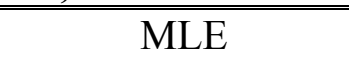 } & \multicolumn{2}{|c|}{ ב HECKIT } \\
\hline & Coefficient & t-ratio & Coefficient & t-ratio & Coefficient & t-ratio \\
\hline$\overline{\text { Constant }}$ & 0.2878 & 2.41 & 0.2840 & 2.49 & 0.2921 & 2.42 \\
\hline Age & 0.0788 & 12.67 & 0.0798 & 10.62 & 0.0808 & 10.12 \\
\hline $\mathrm{Age}^{2}$ & -0.0009 & -11.09 & -0.0009 & -10.52 & -0.0009 & -9.94 \\
\hline Education & 0.0388 & 16.57 & 0.0384 & 13.96 & 0.0382 & 13.45 \\
\hline Midwest & 0.0701 & 2.68 & 0.0691 & 2.52 & 0.0683 & 2.57 \\
\hline South & -0.1575 & -5.85 & -0.1594 & -5.76 & -0.1596 & -5.85 \\
\hline West & -0.0514 & -2.24 & -0.0514 & -2.27 & -0.0507 & -2.20 \\
\hline Black race & -0.1273 & -2.79 & -0.1284 & -2.91 & -0.1287 & -2.81 \\
\hline Asian race & -0.0186 & -0.44 & -0.0100 & -0.19 & -0.0038 & -0.07 \\
\hline Other race & -0.0535 & -0.83 & -0.0566 & -0.96 & -0.0577 & -0.89 \\
\hline Immigrated before 1949 & 0.1046 & 1.36 & 0.1317 & 1.33 & 0.0993 & 1.14 \\
\hline Immigrated 1950-1959 & 0.0698 & 1.16 & 0.0903 & 1.25 & 0.0693 & 1.09 \\
\hline Immigrated 1960-1969 & 0.0586 & 1.38 & 0.0695 & 1.54 & 0.0612 & 1.44 \\
\hline Year 1980 indicator & -0.0485 & -1.96 & -0.0313 & -0.94 & -0.0424 & -1.69 \\
\hline Years since immigration & 0.0157 & 1.88 & 0.0148 & 1.79 & 0.0147 & 1.71 \\
\hline Years since immigration ${ }^{2}$ & -0.0004 & -1.45 & -0.0004 & -1.56 & -0.0004 & -1.47 \\
\hline Sigma (1) & & & 0.5192 & 113.25 & -0.0306 & -0.40 \\
\hline Rho $(1, \mathrm{u})$ & & & -0.0345 & -0.24 & & \\
\hline Lambda & & & & & -0.0306 & -0.40 \\
\hline
\end{tabular}


Table 5b. Estimates of the earnings equations, nonintermarried immigrants.

\begin{tabular}{lrrrrrr}
\hline \hline & \multicolumn{2}{c}{ GLS } & \multicolumn{2}{c}{ MLE } & \multicolumn{2}{c}{ HECKIT } \\
& Coefficient & t-ratio & Coefficient & t-ratio & Coefficient & t-ratio \\
\hline Constant & 0.9485 & 7.25 & 0.7707 & 6.13 & 0.7310 & 4.22 \\
Age & 0.0385 & 5.46 & 0.0478 & 7.79 & 0.0469 & 5.65 \\
Age $^{2}$ & -0.0004 & -4.54 & -0.0005 & -7.02 & -0.0005 & -4.93 \\
Education & 0.0392 & 16.87 & 0.0379 & 18.91 & 0.0363 & 13.02 \\
Midwest & 0.1292 & 4.32 & 0.1246 & 5.09 & 0.1211 & 4.01 \\
South & -0.1232 & -4.27 & -0.1163 & -5.38 & -0.1269 & -4.39 \\
West & -0.0107 & -0.48 & 0.0071 & 0.39 & -0.0026 & -0.12 \\
Black race & -0.1419 & -3.37 & -0.1201 & -3.17 & -0.1435 & -3.41 \\
Asian race & -0.1035 & -3.69 & -0.0822 & -2.95 & -0.0532 & -1.39 \\
Other race & -0.0806 & -1.17 & -0.0815 & -1.59 & -0.0967 & -1.40 \\
Immigrated before 1949 & 0.0370 & 0.47 & -0.0738 & -0.88 & -0.0498 & -0.54 \\
Immigrated 1950-1959 & 0.0106 & 0.19 & -0.0405 & -0.69 & -0.0273 & -0.45 \\
Immigrated 1960-1969 & -0.0112 & -0.33 & -0.0250 & -0.81 & -0.0123 & -0.37 \\
Year 1980 indicator & -0.0485 & -1.96 & -0.0313 & -0.94 & -0.0424 & -1.69 \\
Years since immigration & 0.0309 & 4.35 & 0.0313 & 5.52 & 0.0284 & 3.93 \\
Years since immigration & -0.0006 & -2.52 & -0.0006 & -3.28 & -0.0006 & -2.59 \\
Sigma (0) & & & 0.5335 & 74.00 & & \\
Rho (0,u) & & & 0.2110 & 2.00 & & \\
Lambda & & & & & -0.1743 & -1.91 \\
\hline
\end{tabular}


Table 6. Differences between estimates in earnings equations.

\begin{tabular}{|c|c|c|c|c|c|c|}
\hline & \multicolumn{2}{|c|}{ GLS } & \multicolumn{2}{|c|}{ MLE } & \multicolumn{2}{|c|}{ HECKIT } \\
\hline & Difference & $p$-value & Difference & $p$-value & Difference & $p$-value \\
\hline Age & 0.0403 & 0.0000 & 0.0320 & 0.0010 & 0.0339 & 0.0032 \\
\hline $\mathrm{Age}^{2}$ & -0.0005 & 0.0000 & -0.0004 & 0.0007 & -0.0004 & 0.0004 \\
\hline Education & -0.0004 & 0.8979 & 0.0005 & 0.8879 & 0.0019 & 0.6395 \\
\hline Black race & 0.0146 & 0.8144 & -0.0083 & 0.8866 & 0.0149 & 0.8109 \\
\hline Asian race & 0.0849 & 0.0935 & 0.0722 & 0.2354 & 0.0494 & 0.4666 \\
\hline Other races & 0.0271 & 0.7737 & 0.0249 & 0.7486 & 0.0390 & 0.6812 \\
\hline Immigrated before 1949 & 0.0676 & 0.3837 & 0.2055 & 0.1139 & 0.1491 & 0.1545 \\
\hline Immigrated 1950-1959 & 0.0592 & 0.3445 & 0.1307 & 0.1592 & 0.0966 & 0.1778 \\
\hline Immigrated 1960-1969 & 0.0698 & 0.1504 & 0.0946 & 0.0839 & 0.0735 & 0.1315 \\
\hline Years since migration & -0.0152 & 0.1613 & -0.0165 & 0.0982 & -0.0137 & 0.2189 \\
\hline Years since migration $^{2}$ & 0.0002 & 0.1551 & 0.0002 & 0.4737 & 0.0002 & 0.2137 \\
\hline Assimilation effect & 0.0248 & 0.0540 & 0.0153 & 0.1799 & 0.0199 & 0.1396 \\
\hline
\end{tabular}

Notes:

(1) GLS refers to the generalized least squares (SURE); MLE are the maximum likelihood estimates; HECKIT is the two-step Heckman correction procedure.

(2) Difference indicates the difference between the coefficient estimate between intermarried and nonintermarried earnings equations. P-value is for the test that there is no difference in the coefficient estimates.

(3) The number of observations is 9,192 for MLE estimates, and 6,928 for GLS and HECKIT (3,464 observations for each intermarried and nonintermarried immigrants). 
Table 7. Specification checks

\begin{tabular}{lrrrr} 
Specification & GLS & HECKIT & Lambda1 & Lambda0 \\
\hline All unmarried, 16-65 & 0.0248 & 0.0200 & -0.0306 & -0.1743 \\
& $(0.0540)$ & $(0.1396)$ & $(-0.40)$ & $(-1.91)$ \\
All unmarried, 16-32 & & 0.0242 & -0.0357 & -0.1816 \\
& & $(0.1398)$ & $(-0.48)$ & $(-2.05)$ \\
Never married, 16-65 & & 0.0188 & 0.0020 & -0.1753 \\
& & $(0.1653)$ & $(0.27)$ & $(-1.98)$ \\
Never married, 16-32 & & 0.0190 & -0.0227 & -0.1770 \\
& & $(0.1618)$ & $(-0.31)$ & $(-2.02)$ \\
Completed education & 0.0280 & 0.0127 & 0.0031 & -0.1961 \\
& $(0.0478)$ & $(0.1485)$ & $(0.042)$ & $(-2.19)$ \\
English-speaking & & & & \\
immigrants & 0.0185 & 0.0081 & 0.0325 & -0.2196 \\
& $(0.5781)$ & $(0.8194)$ & $(0.23)$ & $(-1.10)$ \\
\hline
\end{tabular}

